\title{
Thinking about incarceration in South Africa: The Inside-out Outside-in interest group
}

\author{
[ B R I E F I N G ]
}

\begin{abstract}
This article provides a reflective discussion as seen through the gaze of the recently formed Inside-out Outside-in South African Corrections Interest Group, about incarceration and the people who are affected by life inside and outside prisons. The main focus of the White Paper on Corrections in South Africa is the necessity to identify corrections as being focused on rehabilitation and as a responsibility that the Department of Correctional Services shares with society at large. Hawkins (1982) refers to correctional officers as "the other prisoners", and in this reflective discussion, society at large is considered as "the other correctional officers" in reviewing attempts to give substance to the Department of Correctional Services' objectives of corrections and rehabilitation in partnership with society. In particular, community engagement initiatives of the Inside-out Group linked to communities inside and outside the corrections environment in South Africa are highlighted.
\end{abstract}

In a fundamental break with a past archaic penal system in South Africa, prisons "became correctional centres of rehabilitation and offenders are given new hope and encouragement to adopt a lifestyle that will result in a second chance towards becoming the ideal South African citizen" (Foreword by the Minister of Correctional Services, B M N Balfour, Department of Correctional Services, 2005: 5). Super (2011: 210) argues that the "new South African government used the spectacle of the legal to draw a sharp dividing line between the past and the present and the leitmotif of transformation manifested

\section{Eduard Fourie}

Department of Psychology, University of South Africa, Pretoria

fourime@unisa.ac.za

\section{Keywords}

correctional officers, corrections, incarceration, community initiatives, community psychology, offenders, prisons, societal responsibility 
itself in the passage of new legislation and a spate of policy documents". The main focus of the White Paper on Corrections in South Africa is emphasising the necessity to identify corrections as a societal responsibility and also to undertake all departmental tasks to achieve a rehabilitation mission (Department of Correctional Services, 2005). The responsibility for renewing unity at family and community levels lies with the entire society, while the Department of Correctional Services (DCS) has the duty of interpreting the concept of the White Paper into working activities.

From a social constructionist point of view, this article first provides an overview of the life and work of correctional officers in the South African context post the apartheid regime. As the White Paper on Corrections specifically highlight societal responsibility in the rehabilitation of offenders and in the re-integration of ex-offenders into society, the article introduces and shares a range of community engagement initiatives and research studies that are being hosted and facilitated by the interdisciplinary Insideout Outside-in South African Corrections Interest Group hosted in the Department of Psychology at Unisa.

In order to realise the objectives of contemporary correctional institutions, correctional officers are challenged with two often conflicting objectives, that of corrections and rehabilitation. According to Matetoa (2012) the objective of corrections is the duty to society that assures that offenders are confined within appropriate behavioural procedures. The objective of rehabilitation is steered towards staff carrying out treatment that is constructive and that will make sure that when offenders are released, there is a realistic chance for them to turn into productive members of the community. In spite of having a progressive constitution and policy, Matetoa (2012) argues that South Africa continues to be challenged with incidents of retribution in the justice system.

In a telling comment, Hawkins notes that, "It is in fact remarkable how little serious attention has been paid to prison officers in the quite extensive literature on prison life. It is almost as though they were, like the postman in GK Chesterton's celebrated detective story, so commonplace and routine a feature of the scene as yet to be invisible. Yet their role is of critical importance" (cited in Liebling, Price, \& Shefer, 2011: 1). In our reading of South African work, specifically in community psychology, we find very little, if any, publications on corrections and corrections communities.

Correctional officers are responsible for the safety and security of the correctional centres and its inhabitants in addition to providing rehabilitation with the aim of preventing recidivism. According to Siter (as cited in Matetoa, 2012), correctional personnel are skilled professionals. Correctional officer - instead of guard - refers to the duties of custody and control which demand substantial relational skills, exceptional training, and 
education (Seiter, as cited in Matetoa, 2012). Plaatjies (2008) highlights that, according to the White Paper, a correctional officer is defined in terms of their required skills and competencies. These skills and competencies include being a rehabilitator, attending to others, the ability to work with people, multi-functionality and the ability to isolate themselves from corrupt and dishonest practice.

"The other prisoners", the large cohort of correctional officers (Hawkins, 1982), although not formally incarcerated, nevertheless spend most of their waking lives in and around correctional centres. The work by correctional officers is often low visibility work, and the only people who see their daily practices and their working personalities are the offenders. Liebling et al (2011) argue that a correctional officer often needs to function as a supervisor, custodian, disciplinarian, peacekeeper, administrator, observer, manager, facilitator, mentor, provider, classifier and diplomat in one day. Correctional officers have two-fold roles: The roles of corrections, and the role of rehabilitation. These roles are meant to heighten the objectives of modern correctional institutions. On the one hand, the rehabilitation objective refers to anything that is constructive in order to make sure that when offenders are released, there is a genuine opportunity for them to turn into fruitful members of the community (Josi \& Sechrest, 1998). Correctional officers are expected to help offenders, befriend them and encourage them to deal with their offending behaviour (Liebling et al, 2011). They are expected to maintain security and control. But then, conflict lies in the correctional officer being expected to balance security and still be responsible for changing the behaviour of offenders constructively (Josi \& Sechrest, 1998). A recruitment document (Go Study, nd), set out the duties of a correctional officer in South Africa as: "the safe custody of the prisoners in his/her care; the training and treatment of prisoners during their imprisonment; preparation of the prisoners for their release and integration into the community; and relevant administrative work."

Corrections are dynamic environments where events constantly happen - tension between offenders and staff, management changes, disagreements and other general events. These happenings greatly affect the atmosphere of the correctional centre, and when a correctional officer comes back on shift after a week or so off duty, they may find it difficult to catch up with the happenings and changes, as these events can each form or sever bonds, create new "alliances" or just become an anecdote on the correctional centre wing (Liebling et al, 2011). During each moment of the day in a correctional centre, the relationship between correctional officer and offenders matters. This relationship will be used by the officer to assist with sentence plans, while strip searching a prisoner, to censor letters, to console a prisoner and to search a prisoner's cell. Seiter (2012) argues that in view of these complex work demands, correctional officers are required to be knowledgeable and thoroughly trained. 
The bulk of incarcerated sentenced offenders in South African correctional centres have been sentenced to long-term sentences (more than 20 years, including life-sentences) according to the Republic of South Africa's Judicial Inspectorate for Correctional Services Annual Report (cited in Matetoa, 2012). These long-term sentences compel the rehabilitation process to lose its meaning as both offenders and correctional officers may not see the purpose of rehabilitation, thus affecting the motivation of the correctional officers, and their role may revert back to the singular role of security (Matetoa, 2012).

Matetoa (2012) is further of the view that correctional officers have to have a thorough understanding of the concept of the White Paper in order to contribute effectively in the renewal of relations at societal level and even contribute effectively in all the departmental strategic plans that are geared towards rehabilitation. The DCS is aware of the massive difficulty it has to deal with in relation to the changing identity of the correctional officer from that of a prison warder who was observed to be inclined to unethical motivations (Matetoa, 2012). The correctional officer is now expected to be a "role model and a rehabilitator". The correctional officer is seen as best positioned to persuade offenders negatively or positively.

The South African DCS is confronted with staffing challenges when it comes to specific careers within the broader correctional staff. Social workers and psychologists fall under the top vacant positions (Matetoa, 2012). The overall vacancy rate in correctional services during the 2012-2013 period was established to be $4.1 \%$. The vacancy rate for positions in the "rehabilitation" programmes was however considerably higher than the overall rate at $11.6 \%$ (Department of Correctional Services, 2013). Linked with the high vacancy rate in the rehabilitation programmes, is the vacancy rate in the critical occupations that are associated with rehabilitative duties. In addition to the high vacancy rate of psychology professionals, there is also a concerning turnover rate at $10.5 \%$ annual employee turnover (Department of Correctional Services, 2013). Traditionally, rehabilitation is seen as the duty of these professions, and the high vacancy rates disturb the facilitation process of rehabilitation and of gearing the activities of the DCS toward rehabilitation. One can only wonder how these vacancy rates affect the duties and expectations placed upon the correctional officer.

\section{Societal responsibility}

The White Paper sees corrections as much more than just crime prevention, but also as a societal responsibility to which all sectors and institutions of society should contribute and therefore encourages the community to get involved (Department of Correctional Services, 2005). To combat recidivism, social reintegration is seen as the most challenging aspect of rehabilitation, and the period of incarceration should therefore be used to rebuild the relationship between the offender, the community and 
society at large (Department of Correctional Services, 2005). In line with Hawkins' (1982) reference to correctional officers as "the other prisoners", we refer to society as "the other correctional officers".

The Department of Correctional Services (2005: 17-18) provides community participation policy guidelines, and these include amongst others "the creation of an environment that is conducive to the effective involvement of the community in the rehabilitation of the offenders; the creation of opportunities for the establishment and maintenance of partnerships between the DCS and the community; the regulation of the number of community-based service providers wishing to render programmes and services to offenders to assist with rehabilitation efforts; the formalization of collaborative partnerships and networking relationships with the community; the integration and coordination of services rendered to offenders by community based service providers; ensuring effective re-integration of offenders into the community; the involvement of ex-offenders in rehabilitation efforts; and marketing of the Department, its needs and services to the community."

However, it is important to bear in mind that communities themselves are not necessarily ideal rehabilitative environments, but also face numerous social and economic challenges. "The White Paper is mindful of the fact that it is not only those from dysfunctional families that engage in acts of criminality. ... However, a sober analysis of the composition of South Africa's offender population, drives home the reality that the vast majority of our offenders come from communities and families plagued by poverty, hunger, unemployment, absent figures of authority and care ..." (Department of Correctional Services, 2005: 34).

Despite progressive legislation and policy, there seems to be high rates of failure in the implementation of the rehabilitation focused philosophy as set out in the White Paper and arguments are being made that this failure rate is due to the neglect of the human factor (Matetoa, 2012). According to the White Paper: "Moral regeneration and promotion of the ethics enshrined in the Constitution, requires special attention to be paid to the creation of an environment that allows for self-discipline, social independence, ongoing family support and community support as well as reintegration of offenders" (Department of Correctional Services, 2005: 36).

One of the new and positive additions to the Correctional Services Amendment Bill (Act 25) (Parliamentary Monitoring Group, 2008), is the provision that the National Commissioner may allow community-based organisations, non-government organisations and faith-based organisation to interact with sentenced offenders in order to facilitate the rehabilitation and integration of offenders into the community 
(Dissel, 2008). This is again generally in keeping with the DCS vision that "correction is a societal responsibility" and the encouragement of the community to become actively involved in corrections (Dissel, 2008). Many community organisations have taken up the opportunities for engagement offered by the new dispensation. The Inside-out Outsidein South African Corrections Interest Group is one of these.

\section{Towards new community engagement initiatives}

In 2013, a group of community psychology lecturers, students and practitioners, mostly from the Department of Psychology at Unisa began talking about our shared interest and some existing community and research projects already established or imagined in communities in and around corrections. We consequently launched the Insideout Outside-in South African Corrections Initiative. From the onset, we paid specific attention to the assumptions and perspectives underpinning a community psychology approach to psychological practice.

Texts on community psychology in South Africa published during the last two decades cover fundamentally important themes and contexts. These include amongst others:

- an historical perspective on community psychology in South Africa (Duncan, Bowman, Naidoo, Pillay, \& Roos, 2007; Yen, 2007; 2008; Seedat \& Lazarus, 2011);

- teaching community psychology (Carolissen, 2006, 2008; Fourie, Segalo, \& Terre Blanche, 2010; Fynn, Terre Blanche, Fourie, \& Kruger, 2012);

- health and health promotion (Petersen \& Govender, 2012);

- mental health (Freeman, 2012);

- interventions in the context of HIV/Aids (Van der Walt, Bowman, Frank, \& Langa, 2007; Visser, 2012);

- substance abuse (Moleko, 2012);

- poverty and inequality (Mayekiso \& Tshemese, 2007; Ratele, 2012);

- vulnerable communities such as the homeless (Frank, Tshemese, \& Mayekiso, 2007);

- sexism (Shefer, 2004); 
- the elderly (Ntshangase, Duncan, \& Roos, 2007);

- violence against women and children (Kaldine, 2012a);

- crime and violence (Swart, 2007; Kaldine, 2012b);

- race and intergroup relationships (Carolissen, 2006; Duncan, Bowman, Stevens, \& Mdikana, 2007; Zuma \& Durrheim, 2012);

- intergenerational rites of passage (Van der Walt \& Bowman, 2007);

- safety promotion work (Suffla, Kaminer, \& Bawa, 2012);

- collaborative work across the African continent (Lazarus et al, 2006);

- concerns of former combatants who were part of the national liberation military structures in exile (Langa, 2007).

Particularly noteworthy is the relative absence of corrections communities from a discipline that challenges existing power structures and often focuses on the study of those at the margins of society. Some theoretical approaches to power used by community psychologists, such as that of Foucault (1979), indeed sees the prison as emblematic of how power operates throughout society. One reason for the relative absence of corrections studies in South African community psychology may be South Africa's history of racial and economic oppression, which compelled local community psychology practitioners to focus on the more immediate injustices of apartheid and the post-apartheid period.

The need to draw on community or local knowledge in order to understand and respond to particular issues has been addressed in various ways in community psychology, primarily through the emphasis on community or citizen participation (Lazarus, 2007). A psychological sense of community, or the relationship between individuals and the communities they belong to (Lazarus, 2007), is particularly relevant to all stakeholders in communities in and around corrections and correctional services. We acknowledge the challenges relating to intersectoral collaboration (Lazarus, 2007) as of specific relevance when engaging with prison communities and in conducting prison related studies. These challenges, amongst others, include developing a common understanding and commitment to addressing barriers to initiatives; identifying specific stakeholder roles and functions; addressing the many personal and interpersonal challenges of working as a team, including dealing with power dynamics; obtaining resources and institutional 
support from the relevant government departments or community organisations and institutions; and learning to understand each other through developing a common "language" (Lazarus, 2007).

The Inside-out Outside-in South African Corrections community engagement initiative seeks to apply community psychology approaches and perspectives to the diverse communities that exist in and around correctional systems. We are particularly focused on initiatives that cross the boundaries between the inside and outside of prisons. Examples are the development of tertiary education opportunities for offenders, issues of social reintegration and recidivism after release, issues relating to the families and relatives of offenders, and the collaborative generation and dissemination of knowledge about corrections' experiences and circumstances (Inside-out Outside-in, nd).

We have identified corrections studies and corrections communities as part of social justice and inclusion, one of the key research focus areas in the Department of Psychology at Unisa and propose research fields and topics relating to corrections experiences and corrections communities to prospective students. In recent years, a number of postgraduate students have enrolled for Masters and Doctoral degrees on prison communities and issues. We place a strong emphasis on scholarly development and strive to provide spaces for our own students as well as those from other South African universities to develop their research studies as part of the Inside-out Outside-in initiative. Doctoral candidates include Janine Prinsloo who is conducting a study on translating neuropsychological rehabilitation principles into a community psychology approach in order to prevent relapse, and Sebenzile Nkosi who is investigating masculinity and mental health among male offenders in Tshwane, South Africa. At Master's Degree level, Jessuina James is exploring employment expectations of former female offenders while Sibulelo Qhogwana is conducting a narrative analysis of the experience of female offenders' rehabilitation in correctional centres in the Gauteng Province of South Africa. Through narratives of resistance, Mbongiseni Mdakane explores how ex-offenders defy the odds of recidivism.

Mdakane further embarked on a study into the policy and practices of the Health Professions Council of South Africa (HPCSA) and specifically the obstacles experienced by offenders out on parole in registering with the HPCSA as student psychologists. Khonzi Mbatha and Martin Terre Blanche investigated what they term "the long walk to incarceration", namely the difficulties experienced by awaiting trial offenders in contemporary South Africa. Finally, Carien du Plessis and colleagues are working on a history of the Inside-out Outside-in group, including measures that have been taken to ensure that it remains sustainable. 
As mentioned earlier, the Inside-out Outside-in initiative is an inter-disciplinary group that brings together developing and established scholars, practitioners, offenders and ex-offenders and other members of society and therefore includes researchers in disciplines other than psychology as well as from institutions beyond the boundaries of South Africa. We have, for example, been approached by prospective doctoral students and research collaborators from Europe and South America.

Since the inauguration of the Inside-out Outside-in initiative, we had the opportunity to present some of our research projects at conferences, both national and international. We hosted round table discussions and symposia at the $5^{\text {th }}$ International Conference on Community Psychology in Fortaleza, Brazil in September 2014 as well as at the South African Psychology Congress in September 2013, 2014 and 2015. We hosted a pre-conference workshop on corrections community engagement initiatives during the 4th Southern African Students' Psychology Conference that took place in Polokwane, South Africa in June 2015.

Since its launch, the Inside-out Outside-in group also hosted a series of informal gatherings, round table discussions and visits to correctional centres. During these events, ex-offenders, developing and developed scholars, correctional managers and officers and representatives from other disciplines were invited to share ideas. In developing community engagement workshops and hosting symposia, we work closely together with members of the Directorate of Psychological Services of the DCS. A special collaboration is with Edna Freinkel, co-founder of the Readucate Trust in South Africa, a non-government, non-profit making education and literacy organisation that strives to fight illiteracy in corrections (Readucate, nd).

Through creating a facebook interest group, whatsapp group, and a website (http:// insideoutoutsidein.co.za/), we regularly share information about events, research opportunities, book launces, and conferences. In the process, we attempt to function as a networking tool in making connections between practitioners, researchers, students and society in general.

\section{Conclusion}

The Inside-out Outside-in Group came into being at a particular historical junction in South Africa and South African community psychology. As is the case for many other South African institutions, the policy groundwork has been laid for far-reaching reform in the correctional services system. A central element of this reform concerns the crucial importance of communities and community structures in contributing to the rehabilitation of offenders. This provides an opportunity for South African community psychology practitioners to engage with corrections studies after many decades of relative neglect. 
However, one of the key challenges for academics and community activists in becoming involved with correctional processes is the continuing sharp disjuncture between policy imperatives and the challenges of implementation in the day to day running of prisons. While we do not as yet have a clear idea of how to deal with this tension, it is our impression that the inclusive, consultative and inter-disciplinary ethos of the Inside-out Outside-in group provides a good starting point. It is our hope that in time the group will expand to include more South African and international stake holders, and to provide a platform for the voices of offenders as well as professionals.

\section{References}

Carolissen, $\mathrm{R}$ (2006) Teaching community psychology into obscurity: A reflection on community psychology in South Africa. Journal of Psychology in Africa, 16(2), 177-182.

Carolissen, R (2008) Identity and community psychology. A study of psychologists and trainees in the Western Cape (Unpublished doctoral thesis). University of Stellenbosch, South Africa.

Department of Correctional Services (2005) White Paper on Corrections in South Africa. Pretoria: Government Printers.

Department of Correctional Services (2013) Annual Report 2012/2013. http://www.dcs.gov.za/docs/landing/DCS\%20Annual\%20Report\%202012-2013.pdf Accessed: 18 November 2014.

Dissel, A (2008) Correctional Services Act: A survey of the latest amendments. SA prisons at a glance. Civil Society Prison Reform Initiative Newsletter, 27. http://www.communitylawcentre.org.za/cspri. Accessed: 7 December 2014.

Duncan, N, Bowman, B, Naidoo, A, Pillay, J \& Roos, V (eds) (2007) Community psychology: Analysis, context and action. Cape Town: UCT Press.

Duncan, N, Bowman, B, Stevens, G, \& Mdikana, A (2007) Contextual issues: Race and childhood health in South Africa, in Duncan, N. Bowman, B, Naidoo, A, Pillay, J \& Roos V (eds) (2007) Community psychology: Analysis, context and action. Cape Town: UCT Press.

Foucault, M (1979) Discipline and punish: The birth of the prison.

New York: Vintage Books. 
Fourie, E, Segalo, P, \& Terre Blanche, M (2010) Towards an appropriate pedagogy for community psychology: The University of South Africa experience. Acta Academica Supplementum, (2), 22-46.

Frank, J, Tshemese, M, \& Mayekiso, T (2007) Vulnerable communities: The different faces of homelessness, in Duncan, N. Bowman, B, Naidoo, A, Pillay J \& Roos V (eds) (2007) Community psychology: Analysis, context and action. Cape Town: UCT Press.

Freeman, M (2012) Mental health: Interaction with social forces, in Visser, M \& Moleko, A-G (eds) Community psychology in South Africa. Pretoria: Van Schaik Publishers (2007).

Fynn, A, Terre Blanche, M, Fourie, E, \& Kruger, J (2012). Teaching community psychology as community engagement. Journal of Psychology in Africa, 22(4), 575-578.

Go Study (n d) http://www.gostudy.mobi/careers/view.aspx?oid=228 Accessed: 17 January 2015.

Hawkins, G J (1982) The prison: Policy and practice. Chicago: University of Chicago Press.

Inside-out Outside-in (nd) Inside-out Outside-in South African corrections interest group. http://insideoutoutsidein.co.za/Accessed: 15 November 2014.

Josi, D A \& Sechrest, D K (1998) The changing career of the correctional officer. Woburn: Butterworth-Heinemann.

Kaldine, F (2012a) Violence against women and children, in Visser, M \& Moleko, A-G (eds) Community psychology in South Africa. Pretoria: Van Schaik Publishers (2007).

Kaldine, F (2012b) Crime and violence, in Visser, M \& Moleko, A-G (eds)

Community psychology in South Africa. Pretoria: Van Schaik Publishers (2007).

Langa, M (2007) Vulnerable communities: Former combatants in South Africa, in Duncan, N, Bowman, B, Naidoo, A, Pillay, J \& Roos V (eds) (2007) Community psychology: Analysis, context and action. Cape Town: UCT Press.

Lazarus, S (2007) Assumptions and values of community psychology, in Duncan, N, Bowman, B, Naidoo, A, Pillay, J \& Roos V (eds) (2007) Community psychology: Analysis, context and action. Cape Town: UCT Press. 
Lazarus, S, Bojuwoye, O, Chireshe, R, Myambo, K, Akotia, C, Mogaji, A, \& Tchombe, T (2006) Community psychology in Africa: Views from across the continent. Journal of Psychology in Africa, 16(2), 147-160.

Liebling, A, Price, D, \& Shefer, G (2011) The prison officer. Oxon: Willan.

Matetoa, J (2012) The professional role of the correctional officer in the rehabilitation of offenders (Unpublished doctoral thesis). University of South Africa.

Mayekiso, T, \& Tshemese, M (2007) Contextual issues: Poverty, in Duncan, N, Bowman, B, Naidoo, A, Pillay J \& Roos V (eds) (2007) Community psychology: Analysis, context and action. Cape Town: UCT Press.

Moleko, A-G (2012) Substance abuse, in Visser, M \& Moleko, A-G (eds) Community psychology in South Africa. Pretoria: Van Schaik Publishers (2007).

Ntshangase, S, Duncan, N, \& Roos, V (2007) Vulnerable communities: The elderly, in Duncan, N, Bowman, B, Naidoo, A, Pillay, J \& Roos V (eds) (2007) Community psychology: Analysis, context and action. Cape Town: UCT Press.

Parliamentary Monitoring Group (2008) Correctional Services Amendment Bill (B32 - 2007). http://bills.pmg.org.za/bill/454/Accessed: 13 January 2015.

Peterson, I, \& Govender, K (2012) Health and health promotions, in Visser, M \& Moleko, A-G (eds) Community psychology in South Africa. Pretoria: Van Schaik Publishers (2007).

Plaatjies, M F (2008) A model for the implementation of restorative justice in the South African Correctional System. Pretoria: University of South Africa Press.

Ratele, K (2012). Poverty and inequality, in Visser, M \& Moleko, A-G (eds)

Community psychology in South Africa. Pretoria: Van Schaik Publishers (2007).

Readucate (nd) Readucate with an eye on the future. http://www.readucate.org/ Accessed: 25 November 2014.

Seedat, M, \& Lazarus, S (2011) Community psychology in South Africa: Origins, developments, and manifestations. Journal of Community Psychology, 39(3), 241-257. 
Seiter, R P (2012) Correctional administration: Integrating theory and practice. Boston: Prentice Hall (2002).

Shefer, T (2004) Heterosexuality, in Ratele, K, Duncan, N, Hook, D, Mkhize, N, Kiguwa, P \& Collins A (eds) (2004) Self, community and psychology. Cape Town: UCT Press.

Suffla, S, Kaminer, D, \& Bawa, U (2012) Photovoice as community engaged research: The interplay between knowledge creation and agency in a South African study on safety promotion. Journal of Psychology in Africa, 22(4), 517-528.

Super, G (2011) Like some rough beast sloughing towards Bethlehem to be born: A historical perspective on the institution of the prison in South Africa, 1976-2004.

British Journal of Criminology, 51(1), 201-221.

Swart, T (2007) Contextual issues: Power, violence and community psychology, in Duncan, N, Bowman, B, Naidoo, A, Pillay, J \& Roos V (eds) (2007) Community psychology: Analysis, context and action. Cape Town: UCT Press.

Van der Walt, C, \& Bowman, B (2007) Intergenerational rites of passage, in Duncan, N, Bowman, B, Naidoo, A, Pillay, J \& Roos V (eds) (2007) Community psychology: Analysis, context and action. Cape Town: UCT Press.

Van der Walt, C, \& Bowman, B, Frank, J, \& Langa, M (2007) Contextual enablers of the HIV pandemic in South Africa: A community psychology perspective, in Duncan, N, Bowman, B, Naidoo, A, Pillay, J \& Roos V (eds) (2007) Community psychology: Analysis, context and action. Cape Town: UCT Press.

Visser, M (2012) Intervention in the context of HIV/AIDS, in Visser, M \& Moleko, A-G (eds) Community psychology in South Africa. Pretoria: Van Schaik Publishers (2007).

Yen, J (2007) A history of "community" and community psychology in South Africa, in Duncan, N Bowman, B, Naidoo, A, Pillay, J \& Roos V (eds) (2007) Community psychology: Analysis, context and action. Cape Town: UCT Press.

Yen, J (2008) A history of community psychology in South Africa, in van Ommen, C \& Painter, D (eds) Interiors: A history of psychology in South Africa. Pretoria: Unisa Press.

Zuma, B, \& Durrheim, K (2012) Race and intergroup relationships, in Visser, M \& Moleko, A-G (eds) Community psychology in South Africa. Pretoria: Van Schaik Publishers (2007). 